\title{
What Has Happened To International Diversification? Returns, Risks, And Correlations
}

Carl M. Hubbard (E-mail: chubbard@ trinity.edu), Trinity University

\begin{abstract}
Factors other than correlation must be considered in order to understand the reduced diversification effects of EAFE stocks in U. S. portfolio. The diminished importance of EAFE stocks as diversifying securities can be traced first to higher risk in comparison to the $S \& P 500$ and corporate bonds. A comparison of returns to EAFE in the 1990's versus U. S. securities further demonstrates the lack of competitiveness of EAFE stocks for funds in optimized portfolios. Nevertheless, long-term average returns, risks, and correlations provide evidence in support of international diversification of U. S. portfolios.
\end{abstract}

\section{Introduction}

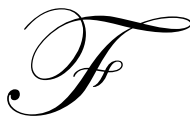

or decades financial literature demonstrated the diversification benefits of including foreign stocks in otherwise domestic U. S. portfolios. In recent years the literature has reported diminished diversification benefits from foreign stocks due to increased correlation between U. S. and foreign stock returns. Others suggest that the increase in correlation between U. S. and foreign stocks occurs primarily in U. S. bear markets when international diversification would be most valuable. This paper documents that change in correlation in the 1990's but also demonstrates how other factors reduced the optimal proportion of foreign stocks in U. S. portfolios even before the changes in correlation occurred. By examining the variables that determine the optimal proportion of foreign stocks in a domestic portfolio we understand the change in the literature on that subject in the 1990's.

Although a number of characteristics may make certain securities attractive to an investor, the analysis in this paper focuses on the basic variables that determine the optimal mixes of risky securities in U. S. portfolios returns in U. S. dollars and the contribution of the security to the risk of portfolios. Monthly returns data for January 1971 through December 2000 provide the data for the calculation of optimal portfolio weights of three investment alternatives - U. S. common stock represented by the S\&P 500 Index, common stock of companies in foreign industrially developed countries represented by Morgan Stanley's EAFE Index, and U. S. corporate bonds represented by the Salomon Brothers Long-Term High-Grade Corporate Bond Index. Those indexes are viewed in this paper as three representative securities that an investor would choose from to optimize a risky portfolio. Optimization is defined here as the mix of securities that maximizes theta, the slope of the capital market line or Sharpe ratio, for the sample period. Once identified, the specific return and risk variables resulting in the optimal weights of the domestic securities in comparison to the weight of EAFE may be examined to understand the varying effects of international diversification on portfolio risk relative to return in the sample time period.

The importance of this subject is found in personal financial planning. The issue is the how the inclusion of a group of foreign stocks may have benefited domestic U. S. portfolios in the 1971 to 2000 time frame. The extra analysis of foreign investments can be time consuming and may require special expertise. Thus the additional search costs require that there be value added when considering any additional category or type of security. This paper provides a historical review of the basic variables that investors consider in making that investment decision. 


\section{Review Of Significant Literature}

Thirty years of literature on the subject of international diversification presents a broad spectrum of research findings on the incremental value of international equity diversification. Early literature from the 1960's and 1970's reported significant benefits, but more recent literature questions the current relevance of the earlier research. One of the conclusions of this paper is that those research results are driven by the returns and risks of foreign and domestic securities in the 1960's and 1970's. Perhaps the earliest article of note on international diversification is Grubel's (1968) article that demonstrated the mean-variance efficiency of international portfolio diversification. The article by Levy and Sarnat (1970) followed and extended the mean-variance efficiency analysis in Grubel's research to include developing countries. Levy and Sarnat demonstrated significant increases in portfolio efficiency in the 1951 - 1967 sample period when stocks from developing countries were included in the sample portfolios.

Investment students are likely to recall graphs similar to those published in a 1974 article by Solnik (1995) that was reprinted in 1995. Solnik calculated systematic risk relative to number of stocks in sample portfolios and provided graphs that illustrate the risk reduction properties of including foreign stocks in otherwise U. S. portfolios. Many textbooks have included Solnik-like graphs to make the same point. See Bodie, Kane and Marcus (2004), Francis and Ibbotson (2002), Jones (2002), and Reilly and Norton (2003). Each text includes some version of Solnik's graphs that illustrate the risk reduction that may be achieved through international diversification.

The literature of the 1990's reveals a shifting of positions on international diversification. Sinquefield (1996) questioned whether adding EAFE to a domestic portfolio of stocks and bonds would increase expected return or reduce risk. He points out that neither theory nor evidence suggests that geography is a systematic risk factor. He argues that the primary risk factors of value and size are present in foreign markets as well as in U. S. markets. Thus one would seek international diversification in the form of specific stocks whose size and value justify their presence in a portfolio. Solnik, Boucelle and Le Fur (1996) reported time varying values of correlation coefficients between U. S. stock returns and foreign stock returns including EAFE stocks during the 1961 to 1994 period. Unlike other more recent studies, Solnik, et al. concluded that the correlation between U. S. stocks and EAFE stocks was not increasing over time. However, they did find that the correlation between the two markets increased in bear markets. Regardless of that finding the authors recommend a portfolio allocation of 20 percent international (EAFE) stocks.

Hanna, McCormack and Perdue (1999) related international diversification to stock in the G-7 countries versus U. S. stocks as represented by Standard \& Poor's 500. In the January 1988 to December 1997 sample period the 100 percent U. S. stocks portfolio was the dominant portfolio. Pairing the Standard \& Poor's 500 returns with returns in each of the other seven markets showed a 74 percent same direction co-movement of the markets. In view of their findings, Hanna, et al. do not accept the conventional wisdom that international diversification reduces portfolio risk. In their analysis of correlation coefficients between returns to Standard \& Poor's 500, the FTSE 100, the CAC 40, the DAX 100, and 10-year U. S. Government bonds, Campbell, Koedijk and Kofman (2002) report evidence of increasing correlation among those markets during bear markets. They tend to agree with others who have concluded that the benefits of international diversification appear to have been diminished by contagious downside volatility.

\section{Data And Methodology}

The analytical process in this paper involves calculating optimal portfolio weights of S\&P 500, EAFE, and corporate bonds for the January 1971 through December 2000 sample period. The analysis is repeated for the two 180 -month periods and again for each of the six 60 -month periods. That treatment of the 360 sample months allows both long-term and shorter-term analysis of the portfolio weights and provides an analysis of the time varying weight of EAFE in the hypothetical portfolios. Since individuals are not likely to engage in regular short selling, short sales or negative weights of securities in optimized portfolios are excluded from this analysis. 
The monthly returns to EAFE in U. S. dollars with dividends reinvested are found on the Morgan Stanley Capital International (MSCI) website, and the monthly total returns to the S\&P 500 index, returns to the Salomon Brothers Index of High-Grade Corporate Bonds, and returns to 30-day U. S. Treasury bills are published by Ibbotson Associates (2003). EAFE is the MSCI index of stock values and returns in the developed markets of European, Australasian, and Far Eastern industrialized countries. According to the MSCI website the EAFE index used in this study is a value-weighted index of total returns to over 1,000 securities originating in 21 industrial countries. In 2001 the stocks in the EAFE Index had a total capitalization of over 6.5 trillion U. S. dollars. EAFE was chosen for this research for two reasons. Previous research has relied on EAFE returns in similar studies, and individuals are more likely to invest in stocks originating in the developed industrial countries that comprise the EAFE Index than in stocks of companies originating in smaller, less developed economies.

Portfolio optimization requires the calculation of returns, standard deviations, and covariances among the securities with the objective of identifying the weights of the candidate securities that result in the maximum excess return/risk tradeoff. Using the average excess returns or risk premiums, standard deviations, and correlations for the various sample periods, the weights that maximized the slope of the capital market line or Sharpe ratio $\left(R_{P}-R_{f}\right) / \sigma_{P}$ were calculated using the optimization routine in Excel/Tools/Solver. The excess return to a portfolio for a sample time period $\left(R_{P}-R_{f}\right)_{t}$ is the weighted average of the average risk premiums or excess returns earned by the three risky securities for that sample time period, or

$$
\left(R_{P}-R_{f}\right)_{t}=\sum_{i=1}^{N} w_{i}\left(R_{i}-R_{f}\right)_{t}
$$

in which $w_{i}$ in Equation (1) is the monthly rebalanced weight of security $i$ in the optimized portfolio and $\left(R_{i}-R_{f}\right)_{t}$ is the risk premium earned by security $i$ in sample period t. Since no short sales were considered, the weights of the securities in the optimized portfolios were constrained to values that are greater than or equal to zero but less than or equal to 1.0, and the sum of the three security weights equals 1.0. The standard deviation of the portfolio $\sigma_{\mathrm{P}}$ for a sample time period is calculated from the variance-covariance equation below.

$\sigma_{p}=\sqrt{\sum_{i=1}^{N} \sum_{j=1}^{N} x_{i} x_{j} \sigma_{i j}}$

Benninga (2000) illustrates the use of Excel's Solver for solving portfolio optimization problems. The objective function is the maximization of the Sharpe ratio, or theta in Benninga, subject to constraints on the values of the weights. The standard deviations of portfolios as defined by Equation (2) were calculated by Excel using variance-covariance matrices from the sample monthly returns. Security returns were sample average excess returns. The optimal weights of the three risky securities and maximized thetas of the portfolios are reported below.

In addition to the optimization analysis, the correlation coefficients among the three risky securities, average returns and standard deviations of returns to the securities for moving 60-month periods are reported in order to understand the changes in the optimal weights of the securities in the optimized portfolios. By examining the optimal weights of EAFE over the 30-year sample period and relating those weights to security return, risk, and correlation, one may observe the causes of shifts in the optimal weight of EAFE in the hypothetical portfolios and understand the 1990's shift in the literature on international diversification.

\section{Results}

Table 1 reports average monthly total returns to 30-day U. S. Treasury bills, EAFE, S\&P 500, and corporate bonds for the full 360 months of the sample period and for non-overlapping sub-periods of 180 months and 60 months. In the first half of the 30-year period the average monthly return to the EAFE Index was 30 basis points higher than the average returns to the S\&P 500. However, in the second half of the sample period, the average 
returns to the S\&P 500 were 28 basis points higher than the EAFE returns. Corporate bond returns were slightly higher in the second 180-month period, and average 30-day Treasury bill returns were 20 basis points lower. The average returns in the six 60-month sample periods show generally increasing average returns to the S\&P 500 and decreasing returns to the EAFE Index after December 1990.

Standard deviations of total returns for the sample period and for sub-periods are also reported in Table 1. The sample standard deviations for EAFE were somewhat higher than those of the S\&P 500, especially in the second 180-month period. However, the final 60-month period is an exception. The standard deviation of S\&P 500 returns was higher than the standard deviation of EAFE returns in the 1996 through 2000 period. The standard deviation of corporate bond returns varied over the 360 months but was materially lower in the second half of the sample period. The comparatively high standard deviations of EAFE returns in the 60 -month periods ending $12 / 31 / 85,12 / 31 / 90$, and 12/31/95 account for the diminished diversification benefits and portfolio weights of EAFE stocks before the EAFE/S\&P 500 correlations increased. When coefficients of variation for EAFE and the S\&P 500 are compared, the EAFE standard deviations of returns relative to mean returns increased above those of the S\&P 500 and corporate bonds in the 1980's and remained higher through the remaining sample data.

Table 1

Monthly Returns, Risk, Correlations, and Optimal Portfolio Proportions of S\&P 500, EAFE, and Corporate Bonds: 1971 - 2000

\begin{tabular}{|c|c|c|c|c|c|c|c|c|c|}
\hline & \multirow{2}{*}{$\frac{360 \text { months ending: }}{12 / 31 / 00}$} & \multicolumn{2}{|c|}{180 months ending: } & \multicolumn{6}{|c|}{60 months ending: } \\
\hline & & $12 / 31 / 85$ & $12 / 31 / 00$ & $12 / 31 / 75$ & $12 / 31 / 80$ & $12 / 31 / 85$ & $12 / 31 / 90$ & $12 / 31 / 95$ & $12 / 31 / 00$ \\
\hline \multicolumn{10}{|l|}{ Average Total Return/Month: } \\
\hline 30-day U. S. Treasury bills & $0.54 \%$ & $0.64 \%$ & $0.44 \%$ & $0.47 \%$ & $0.63 \%$ & $0.82 \%$ & $0.55 \%$ & $0.35 \%$ & $0.42 \%$ \\
\hline EAFE Index & $1.15 \%$ & $1.23 \%$ & $1.06 \%$ & $0.98 \%$ & $1.40 \%$ & $1.32 \%$ & $1.63 \%$ & $0.87 \%$ & $0.69 \%$ \\
\hline S\&P 500 & $1.14 \%$ & $0.93 \%$ & $1.34 \%$ & $0.38 \%$ & $1.18 \%$ & $1.23 \%$ & $1.18 \%$ & $1.33 \%$ & $1.52 \%$ \\
\hline High-grade corporate bonds & $0.76 \%$ & $0.74 \%$ & $0.77 \%$ & $0.52 \%$ & $0.24 \%$ & $1.45 \%$ & $0.86 \%$ & $0.98 \%$ & $0.49 \%$ \\
\hline \multicolumn{10}{|l|}{ Standard Deviations of Monthly Returns: } \\
\hline EAFE Index & $4.88 \%$ & $4.57 \%$ & $5.18 \%$ & $5.24 \%$ & $3.98 \%$ & $4.46 \%$ & $6.58 \%$ & $4.47 \%$ & $4.19 \%$ \\
\hline S\&P 500 & $4.41 \%$ & $4.39 \%$ & $4.43 \%$ & $4.90 \%$ & $4.22 \%$ & $4.02 \%$ & $5.42 \%$ & $2.91 \%$ & $4.64 \%$ \\
\hline High-grade corporate bonds & $2.68 \%$ & $3.24 \%$ & $1.98 \%$ & $2.56 \%$ & $3.07 \%$ & $3.89 \%$ & $2.28 \%$ & $1.77 \%$ & $1.83 \%$ \\
\hline \multicolumn{10}{|l|}{ Coefficients of Variation } \\
\hline EAFE Index & 4.25 & 3.71 & 4.88 & 5.37 & 2.85 & 3.39 & 4.04 & 5.13 & 6.11 \\
\hline S\&P 500 & 3.88 & 4.72 & 3.29 & 12.89 & 3.57 & 3.27 & 4.57 & 2.19 & 3.05 \\
\hline High-grade corporate bonds & 3.55 & 4.40 & 2.55 & 4.93 & 12.77 & 2.68 & 2.67 & 1.81 & 3.76 \\
\hline \multicolumn{10}{|c|}{ Correlation Coefficients of Monthly Returns: } \\
\hline EAFE/S\&P 500 & 0.509 & 0.510 & 0.513 & 0.637 & 0.351 & 0.475 & 0.447 & 0.442 & 0.726 \\
\hline EAFE/Corporate bonds & 0.208 & 0.280 & 0.129 & 0.277 & 0.295 & 0.300 & 0.101 & 0.222 & 0.077 \\
\hline S\&P 500/Corporate bonds & 0.375 & 0.426 & 0.322 & 0.481 & 0.267 & 0.558 & 0.281 & 0.517 & 0.288 \\
\hline \multicolumn{10}{|l|}{ Optimal portfolio proportions: } \\
\hline EAFE Index & 0.323 & 1.000 & 0.050 & 1.000 & 0.710 & 0.284 & 0.287 & 0.000 & 0.000 \\
\hline S\&P 500 & 0.415 & 0.000 & 0.349 & 0.000 & 0.290 & 0.000 & 0.052 & 0.333 & 1.000 \\
\hline High-grade corporate bonds & 0.262 & 0.000 & 0.601 & 0.000 & 0.000 & 0.716 & 0.661 & 0.667 & 0.000 \\
\hline $\begin{array}{l}\text { Maximized theta - } \\
\text { Portfolio risk premium/Risk }\end{array}$ & 0.152 & 0.129 & 0.233 & 0.097 & 0.207 & 0.174 & 0.203 & 0.407 & 0.238 \\
\hline
\end{tabular}

Note: The monthly returns to S\&P 500 Index, 30-day U. S. Treasury bills, and high-grade corporate bonds are those reported by Ibbotson Associates (2002). Monthly returns to the EAFE Index are calculated from the monthly EAFE Index values that include dividends as reported by MSCI at http://www.mscidata.com. Optimal portoflio proportions were calculated from monthly risk premiums earned by the three securities.

Changes in correlations between U. S. stock returns and foreign stock returns have been the subject of debate in recent years. Table 1 reports stable correlations between the S\&P 500 returns and EAFE returns in the 180 -month sample periods, 0.510 versus 0.513 . However, the EAFE/S\&P 500 correlations in the 60 -month periods varied from 0.351 for 1976 through 1980 to 0.726 for 1996 through 2000. The increase in the correlation for the last 60 -month period from 0.442 in the late 1980 's to 0.726 is another reason why the portfolio risk reducing benefits of 
EAFE stocks diminished in the 1990's. Figure 1 plots the values of moving 5-year correlation coefficients of monthly returns to S\&P 500 and EAFE, S\&P 500 and corporate bonds, and EAFE and corporate bonds. The figure shows variable but insignificant change in the S\&P 500/EAFE correlations until the 5-year period ending in 1998. Although the weight of EAFE in the optimized portfolios dropped below 0.30 in the 1980's and to zero in the 1990's, only in the middle and late 1990's did the correlation between those two securities increase beyond 0.50. Thus EAFE's returns and risk in comparison to the returns and risks of S\&P 500 and corporate bonds worked against EAFE's inclusion in the optimized portfolios in the 1990's sample data.

The remaining section of Table 1 reports the optimal weights of S\&P 500, EAFE, and corporate bonds for the sample period. Actual returns, standard deviations, and correlation coefficients rather than anticipated values for those variables were used to calculate the optimal weights of the securities in optimized portfolios. The purpose of the optimizations is not to present the weights that investors should have applied to their portfolios but rather to track and explain the diminishing benefits of international diversification in U. S. portfolios. As can be seen in Table 1, the resulting weight of EAFE in the optimized portfolios decreased from 1.00 in the early 1970's to 0.00 in the 1990's. EAFE was replaced in the portfolios first by corporate bonds in the 1980's and early 1990's and also by S\&P 500 stocks in the 1990's. The final row in Table 1 reports the maximized values of theta or the Sharpe ratio for the sample periods.

\section{Figure 1}

\section{Moving 5-Year Correlation Coefficients of Monthly Returns to S\&P 500, EAFE, and Corporate Bonds: 1971 - 2000}

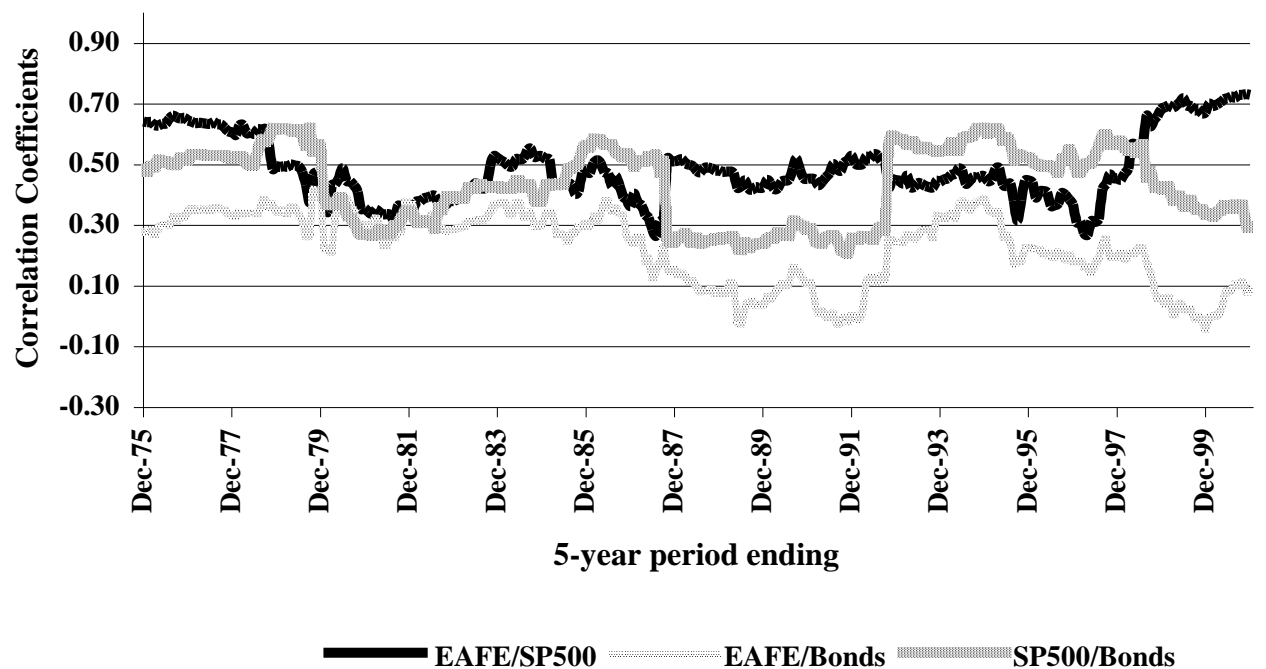

The optimal portfolio weights reported in Table 1 are consistent with a simple CAPM analysis in which EAFE is treated as a security whose beta is calculated as a function of the excess returns to the S\&P 500. Table 2 reports the unadjusted betas of EAFE, average S\&P 500 risk premiums, calculated equilibrium EAFE risk premiums, which are calculated by multiplying the EAFE betas times the average S\&P 500 risk premiums, the realized EAFE risk premiums, and the resulting alphas, which are the realized EAFE risk premiums less the equilibrium EAFE risk premiums for the sample periods. 
Table 2

A CAPM Analysis of Equilibrium EAFE Risk Premiums in Comparison to Realized Risk Premiums

\begin{tabular}{lcccccc} 
Sample Dates & $\begin{array}{c}\text { Sample size } \\
\text { (Months) }\end{array}$ & $\begin{array}{c}\text { EAFE } \\
\text { Betas }\end{array}$ & $\begin{array}{c}\text { S\&P 500 Risk } \\
\text { Premiums }\end{array}$ & $\begin{array}{c}\text { Equilibrium } \\
\text { EAFE Risk } \\
\text { Premiums }\end{array}$ & $\begin{array}{c}\text { Realized } \\
\text { EAFE Risk } \\
\text { Premiums }\end{array}$ & $\begin{array}{c}\text { EAFE } \\
\text { Alphas }\end{array}$ \\
\hline Jan 71 - Dec 00 & 360 & 0.569 & 0.0058 & 0.0033 & 0.0059 & 0.0026 \\
Jan 71 - Dec 75 & 60 & 0.689 & -0.0009 & -0.0006 & 0.0051 & 0.0057 \\
Jan 76 - Dec 80 & 60 & 0.336 & 0.0056 & 0.0019 & 0.0077 & 0.0059 \\
Jan 81 - Dec 85 & 60 & 0.546 & 0.0030 & 0.0016 & 0.0042 & 0.0026 \\
Jan 86 - Dec 90 & 60 & 0.547 & 0.0063 & 0.0035 & 0.0107 & 0.0073 \\
Jan 91 - Dec 95 & 60 & 0.685 & 0.0098 & 0.0067 & 0.0052 & -0.0015 \\
Jan 96 - Dec 00 & 60 & 0.657 & 0.0110 & 0.0072 & 0.0026 & -0.0046 \\
\hline
\end{tabular}

Note: EAFE betas are linear regression coefficients of monthly EAFE risk premiums earned as a function of S\&P 500 risk premiums. Risk premiums are monthly returns less monthly returns on 30-day U. S. Treasury bills as reported by Ibbotson Associates (2002). All betas are significant at the 0.01 level or better.

The alphas reported in Table 2 are positive for the first four 60 -month sample periods, which coincides with the non-zero optimal portfolio weights of EAFE that are reported in Table 1. The negative alphas for the 1990's were the result of the higher betas and lower risk premiums earned by EAFE stocks in the 1990's. The higher EAFE beta in the early 1990's was the result of a lower variance of S\&P 500 returns, and the higher beta in the late 1990's was due to the higher correlation between EAFE and S\&P 500 returns. The negative EAFE alphas in Table 2 coincide with the zero optimal proportions of EAFE that are reported in Table 1.

\section{Discussion And Conclusions}

The diminished importance of EAFE stocks in the 1980's and early 1990's as diversifying securities can be traced primarily to higher risk in comparison to the S\&P 500 and corporate bonds. The higher correlation of EAFE stocks with U. S. stocks is a factor in the decline of optimal weights of those stocks in U. S. portfolios but only in the second half of the 1990's. Factoring in returns to EAFE versus the other securities further demonstrates the obvious lack of competitiveness of EAFE stocks for funds in optimized portfolios.

Returns and risks of corporate bonds also played a role in the reduced weight of EAFE stocks in the efficient portfolios. As reported in Table 1, U. S. corporate bond returns exceeded the returns to EAFE stocks in the early 1980's and early 1990's, and the variance of bond returns was always lower in the sample periods than the variance of returns to EAFE stocks. The unusual return/risk characteristics of corporate bonds in the early 1980's and early 1990's diminished the optimal weights of both stock indexes in the efficient portfolios.

Overall the analysis in this paper agrees with Singuefield's (1996) basic conclusion that security risk factors do not have geographically different expected returns. Thus securities should be evaluated according to value and size characteristics regardless of national origin. However, the following evidence from long-term analysis also supports the notion that foreign stocks as a sector still should be included in U. S. portfolios:

- $\quad$ The 30-year average correlation of returns to the EAFE Index relative to the S\&P 500 Index is 0.48 and 0.22 relative to corporate bonds.

- $\quad$ The 30-year average monthly return to EAFE is very similar to the average return to the S\&P 500 .

- The long-term average standard deviation of monthly returns of EAFE is not materially greater than the standard deviation of S\&P 500 returns.

- $\quad$ The rise in correlation between EAFE and the S\&P 500 is a very recent phenomenon and, in view of the variability of that statistic over time, should not be considered as necessarily permanent. 
Although various theories suggest that the recent higher correlation will persist, history suggests otherwise. Finally, the return/risk dominance of the U. S. stocks of the 1990's has already diminished, and the long-run average EAFE weight of 0.32 of the value of risky securities in a portfolio based on expected returns and risk seems to make sense as a planning guide for including foreign stocks in U. S. portfolios.

\section{References}

1. Benninga, Simon. 2000. Financial Modeling, $2^{\text {nd }}$ edition. Cambridge: The MIT Press.

2. Bodie, Zvi, Alex Kane, and Alan J. Marcus. 2004. Essentials of Investments, $5^{\text {th }}$ edition. New York: McGraw-Hill/Irwin.

3. Campbell, Rachel, Kees Koedijk, and Paul Kofman. 2002. "Increased Correlation in Bear Markets", Financial Analysts Journal, vol. 58, no. 1 (January/February): 87-94.

4. Grubel, Herbert G. 1968. "Internationally Diversified Portfolios: Welfare Gains and Capital Flows", The American Economic Review, vol. 58, no. 5 (December): 1299-1314.

5. Francis, Jack C. and Roger Ibbotson. 2002. Investments. Upper Saddle River, New Jersey: Prentice-Hall.

6. Hanna, Michael E., Joseph P. McCormack, and Grady Perdue. 1999. "A Nineties Perspective on International Diversification", Financial Services Review, vol. 8, no. 1: 37-45.

7. Ibbotson Associates. 2003. Stocks, Bonds, Bills, and Inflation 2003 Yearbook. Chicago, IL: Ibbotson Associates.

8. Jones, Charles P. 2002. Investments Analysis and Management, $8^{\text {th }}$ edition. New York: John Wiley \& Sons.

9. Levy, Haim and Marshall Sarnat. 1970. "International Diversification of Investment Portfolios", The American Economic Review, vol. 60, no. 4 (September): 668-675.

10. MSCI Performance at http://www.mscidata.com/mstool/mstool.wsx.

11. Reilly, Frank K. and Edgar A. Norton. 2003. Investments, $6^{\text {th }}$ edition. Mason, Ohio: South-Western.

12. Sinquefield, Rex A. 1996. "Where Are the Gains from International Diversification?" Financial Analysts Journal, vol. 52, no. 1 (January/February): 8-14.

13. Solnik, Bruno H. 1974. "Why Not Diversify Internationally Rather Than Domestically?" Financial Analysts Journal, vol. , no. 4 (July/August): 48-54. Reprinted in the 1995 Financial Analysts Journal, vol. 51, no. 1 (January/February): 89-94.

14. Solnik, Bruno, Cyril Boucelle, and Yann Le Fur. 1996. "International Market Correlation and Volatility", Financial Analysts Journal, vol. 52, no. 5 (September/October): 17-33. 
Notes 